\title{
BIO-DIESEL DARI TANAMAN JARAK PAGAR SEBAGAI BAHAN BAKAR PENGGANTI SOLAR
}

\author{
Oleh \\ Gede Widayana \\ Jurusan Teknik Elektronika, FTK, UNDIKSHA
}

\begin{abstract}
ABSTRAK
Peningkatan kebutuhan bahan bakar minyak tidak dapat dihindari dan akan terus meningkat dengan semakin banyaknya populasi manusia, munculnya industriindustri dan semakin berkembangnya teknologi otomotif. Majunya penelitian dan penggunaan motor diesel pada industri tidak akan mungkin berhenti hanya karena menipisnya bahan bakar fosil. Pencarian bahan bakar alternatif sebagai pengganti solar terus dilakukan disamping untuk menangani permasalahan krisis energi dan lingkungan global juga dapat membantu dalam mengembangkan teknologi otomotif sebagai karya budaya manusia.

Diesel merupakan Bahan Bakar Nabati yang dapat digunakan untuk menggerakkan mesin diesel . Pembuatan biodiesel dari tanaman jarak pagar ( Jatropha curcas Linneaus ) merupakan sumber energi alternatif pengganti solar.Proses pembuatan mulai dari biji jarak sampai menghasilkan minyak jarak dilanjutkan dengan proses transesterifikasi yang sempurna akan menghasilkan biodiesel murni yang baik sesuai dengan standar mutu yang diharapkan.
\end{abstract}

Kata kunci : Bio Diesel, bahan bakar alternatif, transesterifikasi.

\begin{abstract}
A requirement of oil fuel will increasing with more human being population, industrial and expand automotive technological. The research of diesel engine will be non-stoped progessively go forward. Alternative fuel was searched to handle the problem of energy crissis and can assist in developing technology automotive.

Biodiesel is represent the vegetation fuel which can be used to move the diesel engine. Biodiesel making from Jarak Pagar ( Jatropha curcas Linnaeaus ) is representing source of alternative energy substitution of solar. Making process from seed yield the castor oil countinued the transisterifikasi process will yield biodiesel purification as according to expected quality standard.
\end{abstract}

Keyword : Biodiesel, alternative fuel, transisterifikasi. 


\section{PENDAHULUAN}

Dengan terus naiknya Bahan Bakar Minyak (BBM) akan pasti menambah beban masyarakat, apalagi kondisi ekonomi yang semakin sulit. Selama ini masyarakat Indonesia hanya bergantung pada kebutuhan energi BBM untuk pembangkit tenaga motor bakar pada sumber energi minyak dari fosil. Padahal cadangan minyak bumi semakin tipis dan akan habis dalam beberapa tahun mendatang . Peningkatan kebutuhan bahan bakar minyak tidak dapat dihindari dan akan terus meningkat dengan semakin banyaknya populasi manusia, munculnya industri-industri dan semakin berkembangnya teknologi otomotif. Dengan majunya penelitian dan penggunaan motor diesel pada industri tidak akan mungkin berhenti hanya karena menipisnya bahan bakar fosil. Pencarian bahan bakar alternatif sebagai pengganti solar terus dilakukan disamping untuk menangani permasalahan krisis energi dan lingkungan global juga dapat membantu dalam mengembangkan teknologi otomotif sebagai karya budaya manusia.

Tabel 1. Kebutuhan Bahan Bakar di Indonesia

\begin{tabular}{|c|l|}
\hline TAHUN & \multicolumn{1}{|c|}{ KETERANGAN } \\
\hline $1996-1997$ & Kebutuhan solar 19,3 juta kiloliter \\
\hline $1997-1998$ & Kebutuhan solar 22,2 juta kiloliter \\
\hline $1999-2000$ & Impor BBM dalam negeri 31.707 juta kiloliter \\
\hline 2000 & Impor 5 - 6 miliar liter pertahun \\
\hline 2005 & $\begin{array}{l}\text { Subsidi solar banyak dihapus dan harga minyak disesuaikan } \\
\text { dengan harga minyak dunia. }\end{array}$ \\
\hline $2007-2015$ & Kebutuhan solar 19.3 juta kilo liter. \\
\hline
\end{tabular}

Kompas, 2002.

Dari tabel diatas dapat terlihat bahwa Indonesia sudah menjadi net importir minyak, sehingga dapat dikatakan permasalahan energi sudah merupakan hal yang serius untuk ditangani. 
Hingga saat ini Indonesia masih sangat bergantung pada bahan bakar berbasis fosil sebagai sumber energi. Data yang didapat dari Departemen Energi dan Sumber Daya Mineral menunjukkan bahwa dengan persediaan minyak mentah di Indonesia, yaitu sekitar 9 milyar barrel, dan dengan laju produksi rata-rata 500 juta barrel per tahun, persediaan tersebut akan habis dalam 18 tahun. Untuk mengurangi ketergantungan terhadap minyak bumi dan memenuhi persyaratan lingkungan global, satu-satunya cara adalah dengan pengembangan bahan bakar alternatif ramah lingkungan. Salah satu adalah BIODIESEL.

Biodiesel sebenarnya lebih tepat disebut dengan FAME (fatty acid methyl ester ), yang merupakan Bahan Bakar Nabati yang dapat digunakan untuk menggerakkan mesin diesel sebagai pengganti solar. BBN ini berasal dari minyak nabati yang dikonversi melalui reaksi fisika dan kimia.

Pemilihan biodiesel sebagai bahan bakar alternatif berbasis pada ketersediaan bahan baku. Minyak rapeseed adalah bahan baku untuk biodiesel di Jerman dan kedelai di Amerika. Sedangkan bahan baku yang digunakan di Indonesia adalah crude palm oil (CPO). Selain itu, masih ada potensi besar yang ditunjukan oleh minyak jarak pagar (Jathropa Curcas) dan lebih dari 40 alternatif bahan baku lainnya di Indonesia.

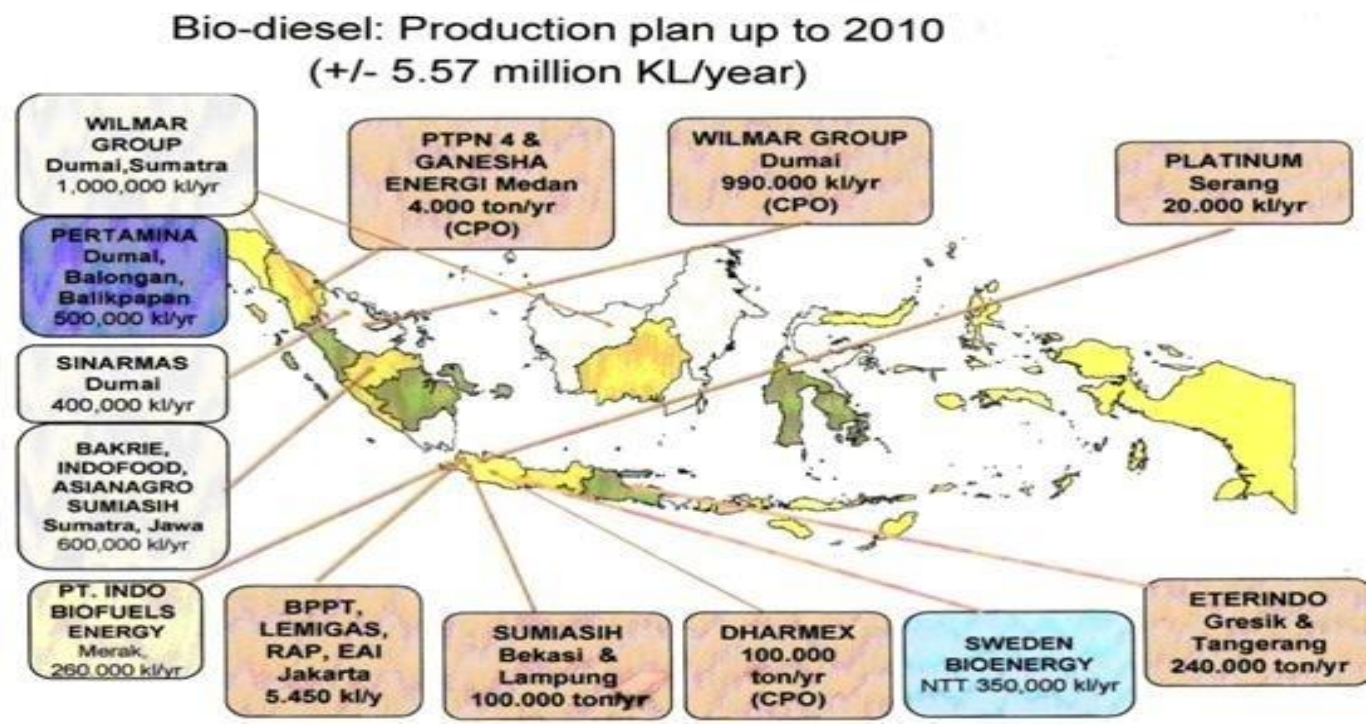

Gambar 1. Rancangan fasilias produksi biodiesel (INBT 2008) 
Indonesia adalah penghasil minyak sawit terbesar kedua setelah Malaysia dengan produksi CPO sebesar 8 juta ton pada tahun 2002 dan akan menjadi penghasil CPO terbesar di dunia pada tahun 2012. Dengan mempertimbangkan aspek kelimpahan bahan baku, teknologi pembuatan, dan independensi Indonesia terhadap energi diesel, maka selayaknya potensi pengembangan biodiesel merupakan potensi pengembangan biodiesel sebagai suatu alternatif yang dapat dengan cepat diimplementasikan.

Walaupun pemerintah Indonesia menunjukkan ketertarikan yang besar terhadap pengembangan biodiesel, pemerintah tetap bergerak pelan dan juga berhati-hati dalam mengimplementasikan hukum pendukung bagi produksi biodiesel. Pemerintah memberikan subsidi bagi biodiesel, bio-premium, dan biopertamax dengan level yang sama dengan bahan bakar fosil, padahal biaya produksi biodiesel melebihi biaya produksi bahan bakar fosil. Hal ini menyebabkan Pertamina harus menutup sendiri sisa biaya yang dibutuhkan.

Hingga Mei 2007, Indonesia telah memiliki empat industri besar yang memproduksi biodiesel dengan total kapasitas 620.000 ton per hari. Industri-industri tersebut adalah PT Eterindo Wahanatama (120.000 ton/tahun - umpan beragam), PT Sumi Asih (100.000 ton/tahun - dengan RBD Stearin sebagai bahan mentah), PT Indo BBN (50.000 ton/tahun - umpan beragam), Wilmar Bioenergy (350.000 ton/tahun dengan CPO sebagai bahan mentah), PT Bakrie Rekin Bioenergy (150.000 ton/tahun) dan PT Musim Mas (100.000 ton/tahun). Selain itu juga terdapat industriindustri biodiesel kecil dan menengah dengan total kapasitas sekitar 30.000 ton per tahun, seperti PT Ganesha Energy, PT Energi Alternatif Indonesia, dan beberapa BUMN.

Peluang untuk mengembangkan potensi pengembangan biodiesel di Indonesia cukup besar, mengingat saat ini penggunaan minyak solar mencapai sekitar $40 \%$ penggunaan BBM untuk transportasi. Sedang penggunaan solar pada industri dan PLTD adalah sebesar 74\% dari total penggunaan BBM pada kedua sektor tersebut. Bukan hanya karena peluangnya untuk menggantikan solar, peluang besar biodiesel juga disebabkan kondisi alam Indonesia. Indonesia memiliki beranekaragam tanaman yang dapat dijadikan sumber bahan bakar biodiesel seperti 
kelapa sawit dan jarak pagar. Pada saat ini, biodiesel (B-5) sudah dipasarkan di 201 pom bensin di Jakarta dan 12 pom bensin di Surabaya.

Pada makalah ini menyajikan cara pembuatan biodiesel secara umum dari tanaman jarak pagar ( Jatropha curcas Linneaus ) yang dapat digunakan sebagai sumber energi alternatif pengganti solar.

Banyak manfaat yang bisa didapat dari pembuatan biodiesel dengan menggunakan minyak tanaman jarak pagar ini. Dimana hasil pengepresan biji tanaman jarak pagar ini akan mendapatkan ampas yang dapat digunakan juga sebagai pupuk, pakan ternak, dan bahan bakar padat.

Jarak pagar merupakan tanaman yang dapat tumbuh dilahan kritis dan tidak memerlukan perawatan yang khusus. Usia tanaman ini bisa mencapai 50 tahun dan bisa mulai berbuah pada umur 5 bulan. Produktifitasnya bisa mencapai $2,5 \mathrm{~kg}$ biji kering perpohon. Dalam 1 Ha lahan bisa menghasilkan 4-5 ton biji kering dalam setahun, dimana 1 ton biji kering menghasilkan 200 - 300 liter minyak jarak.

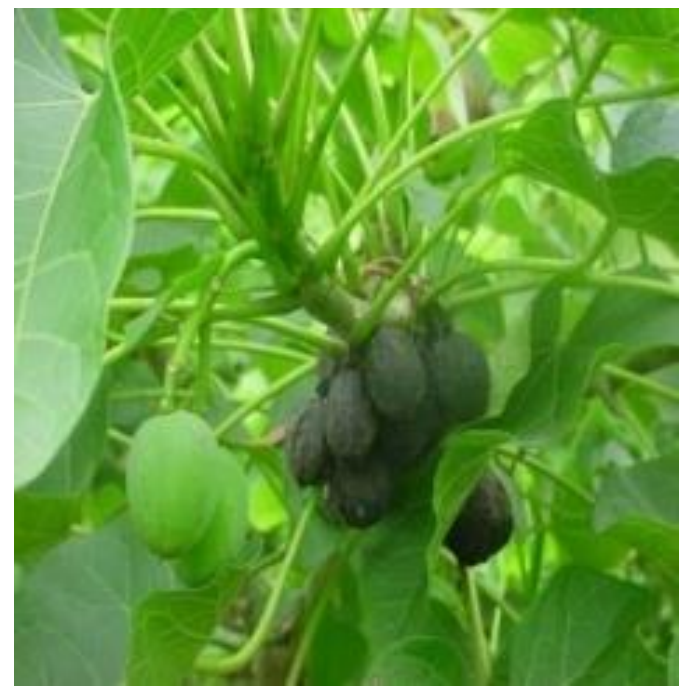

Gambar 2. Tanaman Jarak pagar (Jatropha curcas Linneaus)

Keunggulan dari tanaman jarak pagar ini adalah

1. Tanaman ini dapat tumbuh dan beradaptasi pada tanah berpasir, tanah berkerikil, tanah kering maupun tanah yang mengandung garam).

2. Tidak memerlukan perawatan yang khusus. 
3. Dapat mudah berkembang biak.

4. Tahan terhadap berbagai cuaca.

5. Tahan terhadap hama dan tidak dikonsumsi oleh ternak.

6. Dapat bertahan lama pada kondisi kering.

7. Pertumbuhan cepat dan dapat dipanen pada usia 6-8 bulan.

8. Umurnya panjang (40-50 tahun).

9. Ampasnya dapat dipakai pupuk.

10. Cocok untuk tanaman penghijauan dan reboisasi.

\section{Minyak Jarak}

Proses pembuatan minyak jarak yaitu dengan cara ekstraksi minyak jarak dari bijinya. Dimana proses ekstraksi minyaknya ada dua cara yaitu secara kimia dan secara mekanik. Ekstraksi secara kimia menggunakan pelarut dimana menghasilkan tingkat ekstraksi yang tinggi namun biayanya mahal. Untuk proses ekstraksi secara mekanik sangat cocok sekali dipakai untuk industri-industri kecil. Alur proses pembuatan minyak jarak dapat dilihat pada gambar di bawah.

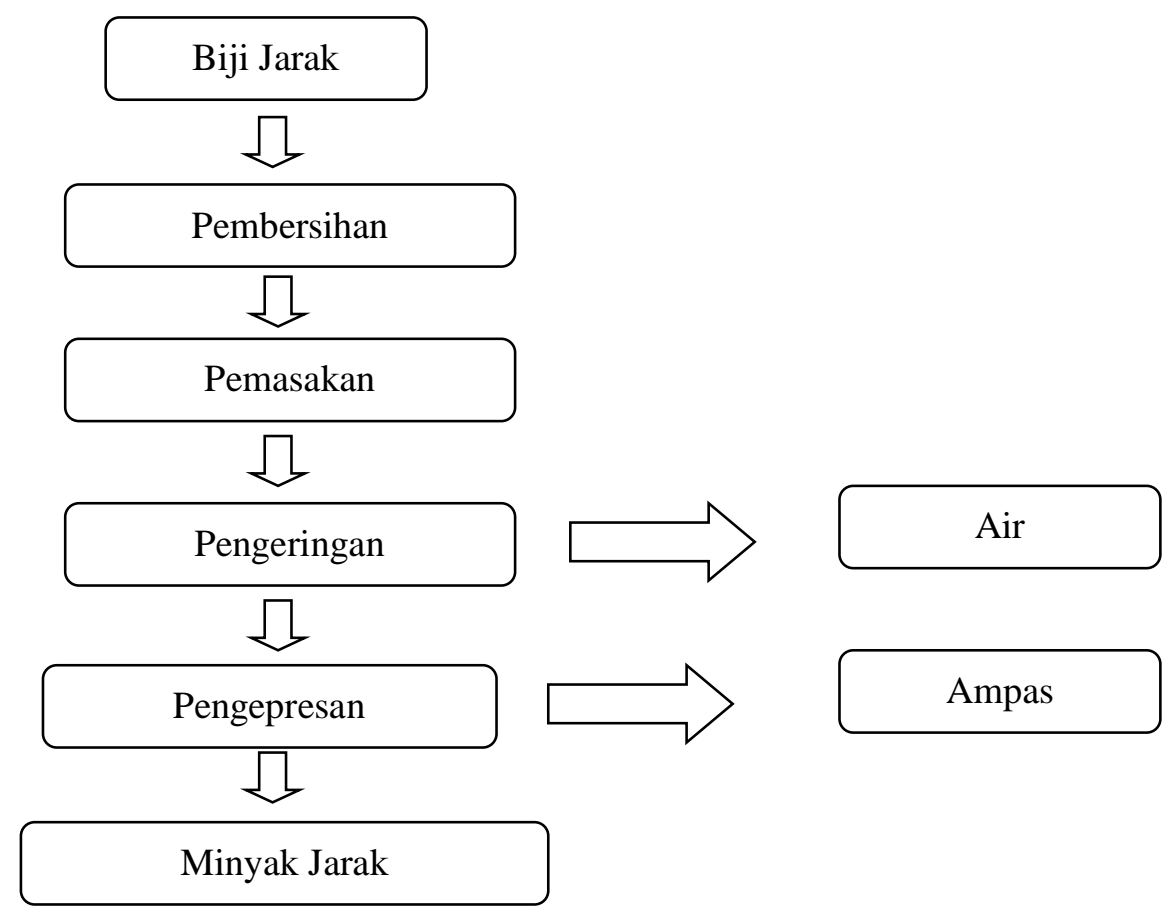




\section{PEMBAHASAN}

\subsection{Proses Pembuatan BioDiesel}

Proses pembuatan biodiesel dimulai dengan proses pembuatan minyak jarak dari biji tanaman jarak pagar, kemudian dari minyak jarak ini dilakukan proses transesterifikasi dengan katalis untuk mendapatkan minyak biodiesel. Adapun tahaptahap proses pembuatannya dapat dilihat dibawah ini.

\subsubsection{Proses Pembuatan Minyak Jarak}

Proses pembuatan minyak jarak dan tahap-tahapannya dijelaskan seperti di bawah ini.

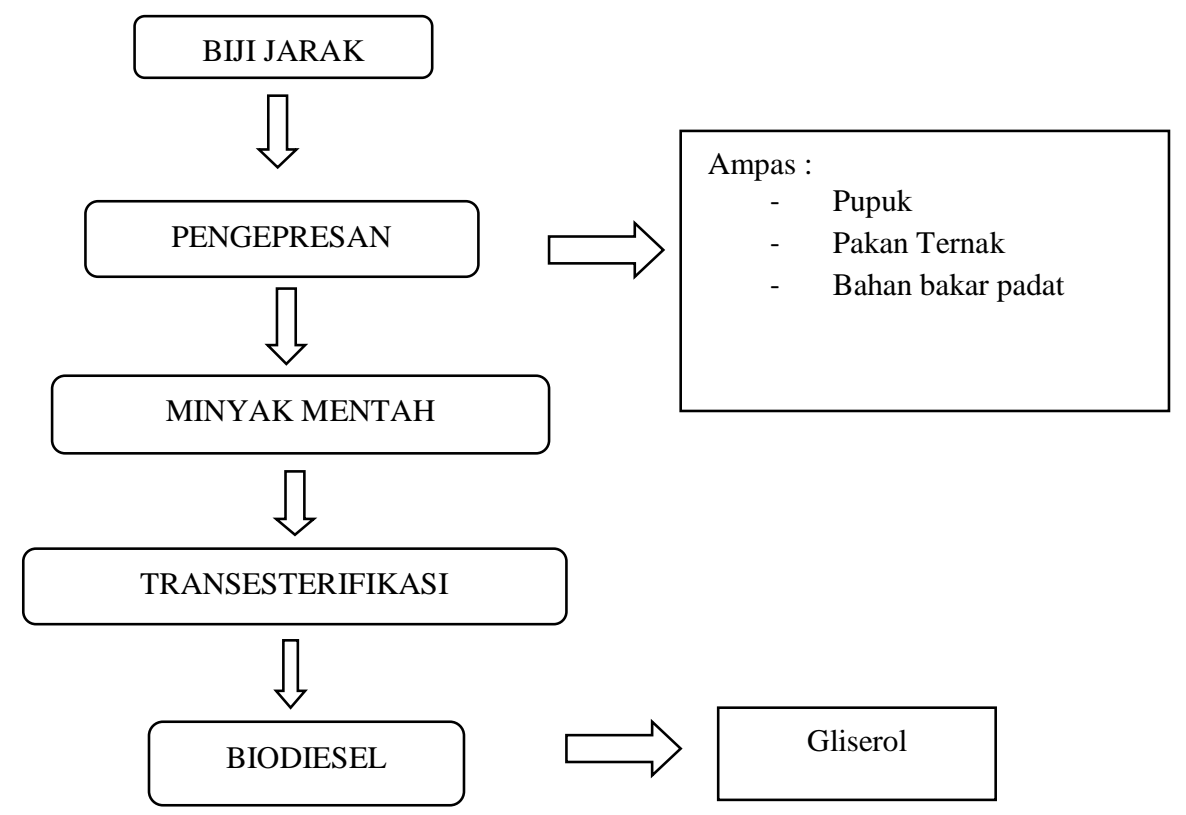

Biji jarak yang telah dipisahkan dari kulitnya dibersihkan dari kotoran-kotoran seperti tanah, kerikil, ranting, dan sebagainya. Biji jarak yang sudah bersih dimasak pada suhu $80^{\circ} \mathrm{C}$ pada kondisi kedap udara. Tujuannya adalah untuk menggumpalkan proein sehingga proses ekstraksi lebih efisien. Setelah dimasak, biji dikeringkan pada suhu $100^{\circ} \mathrm{C}$ sampai kadar air mendekati $4 \%$. Biji yang telah kering kemudian dipres dan minyak yang didapatkan disaring dan ditampung pada wadah, sedangkan ampasnya dihancurkan dan dapat dijadikan pupuk. 


\subsubsection{Proses Transesterifikasi}

Transesterifikasi definisinya adalah penukaran grup alkooxy dari ester dengan alkohol lain. Reaksi ini melibatkan katalis dengan cara menambahkan asam atau basa(Anonim,2005). Asam dapat mengkatalis reaksi dengan cara mendonorkan elektron ke grup alkoxy, sehing dapat membuat gugus ini lebih reaktif. Sedangkan basa berfungsi sebagai katalis dalam reaksi dengan cara menarik elektron dari alkohol .

Urutan proses transesterifikasi adalah sebagai berikut :

1. Isi fluida pelapis pada ruang pelapis.

2. Isikan minya jarak pada wadah dan tutup wadah proses.

3. Panaskan minyak sampai suhu $55^{\circ} \mathrm{C}$.

4. Jalankan motor pengaduk dan masukkan methoksida sedikit demi sedikit.

5. Lakukan pengadukan selama lebih dari 20 menit dan kontrol suhu selama proses.

6. Matikan motor dan pemanas, dan keluarkan hasil proses melalui kran pengeluaran.

\subsubsection{Pengendapan}

Pengendapan dilakukan dengan cara yaitu memindahkan campuran hasil transesterifikasi ke dalam botol gelas dan ditutup segera. Lama pengendapan pada botol gelas, 12-24 jam. Pengendapan akan menghasilkan Glyserin dan methyl ester. Glyserin adalah zat yang mengendap dibagian bawah dan berwarna gelap dan methyl ester berupa cairan yang berada di bagian atas.

\subsubsection{Pencucian}

Pencucian bertujuan untuk memisahkan ester dari katalisator basa dengan menggunakan media air. Disamping itu juga pencucian ini bertujuan untuk mengikat sabun sebagai produk samping transesterifikasi.

Biodiesel sebelum dicuci dengan sesudah dicuci memiliki warna dan tingkat kekeruhan yang berbeda. Biodiesel yang sudah dicuci memiliki warna yang cerah dan bening sedangkan sebelum dicuci memiliki warna yang keruh. 


\subsubsection{Pengeringan}

Proses pengeringan biodiesel dilakukan dengan cara memanaskan secara hati-hati pada suhu $48^{\circ} \mathrm{C}$ dan setelah itu dilakukan pendinginan. Biodiesel yang sudah dikeringkan memiliki warna lebih bening jika dibandingkan dengan yang belum dikeringkan.

\subsection{Pengujian Mutu Biodiesel}

Pengujian mutu biodiesel sesuai standar hanya bisa dilakukan di laboratorium.

Untuk keperluan sendiri dapat dilakukan pengujian sederhana yaitu dengan mengecek tingkat kebersihan biodiesel dari air dan katalis. Biodiesel yang bagus adalah berwarna bening, tembus cahaya dan memiliki pH 7.

Sedangkan untuk standar mutu Biodiesel yang baku selama ini adalah seperti pada Tabel di bawah.

Tabel 2. Standar Mutu Biodiesel

\begin{tabular}{|c|c|c|c|}
\hline Sifat Bahan Bakar & Satuan & $\begin{array}{c}\text { DIN } 51606 \\
\text { Standar Jerman } \\
\end{array}$ & $\begin{array}{c}\text { US ASTM } \\
\text { Standar USA }\end{array}$ \\
\hline Titik Bakar & ${ }^{\circ} \mathrm{C}$ & $100 \mathrm{~min}$ & $100 \mathrm{~min}$ \\
\hline Kandungan Air & Vol \% & - & 0,05 \\
\hline Residu karbon & $\mathrm{Wt} \%$ & $0,3 \max$ & $0,05 \max$ \\
\hline Abu sulfat & $\mathrm{Wt} \%$ & - & $0,02 \max$ \\
\hline Viskositas & $\mathrm{CSt}$ & $3,5-5$ & $1,96-6,5$ \\
\hline Kadar belerang & $\mathrm{Wt} \%$ & $0,01 \max$ & $0,05 \max$ \\
\hline Bilangan setana & - & $49 \min$ & $40 \mathrm{~min}$ \\
\hline Ttik embun & ${ }^{\circ} \mathrm{C}$ & - & $3^{\circ} \mathrm{C}$ \\
\hline Karat tembaga & - & $1 \max$ & $3 \mathrm{~B} \max$ \\
\hline Jumlah asam & $\mathrm{mg} / \mathrm{g}$ & $0,5 \max$ & $0,8 \max$ \\
\hline Gliserin bebas & $\mathrm{Wt} \%$ & $0,02 \max$ & $0,02 \max$ \\
\hline Total Gliserida & $\mathrm{Wt} \%$ & $0,25 \max$ & $0,24 \max$ \\
\hline
\end{tabular}

Anonim,2001 
Biodiesel merupakan sumber energi alternatif pengganti solar dari minyak tumbuhan atau lemak hewan dengan tidak mengandung sulfur dan tidak bearoma. Beberapa penelitian tentang biodiesel yang telah dilakukan adalah :

a. Penggunaan biodiesel langsung dari minyak tanaman murni memerlukan sedikit modifikasi dari konstruksi motor diesel.

b. Pencampuran minyak tanaman dengan minyak solar ( $1: 5$ ), dimana campuran ini dikenal dengan nama nature diesel ( NADI ).

c. Proses transesterifikasi minyak tanaman menggunakan katalis asam atau basa. Hasil proses ini dikenal dengan nama BIODIESEL.

Pada proses transesterefikasi menggunakan ester karena sifat fisiko-kimia ester mendekati sifat fisiko-kimia minyak solar sehingga pada aplikasinya dilapangan tidak memerlukan modifikasi konstruksi motor.

Dibanding dengan bahan bakar solar, biodiesel memiliki beberapa keunggulan yaitu

1. Bahan baku Biodiesel dapat diperbaharui.

2. Kandungan cetane biodiesel yang tinggi dengan volatile yang rendah dan bebas sulfur.

3. Ramah lingkungan karena tidak ada emisi $\mathrm{SO}_{\mathrm{x}}$.

4. Kemampuan melumasi mesin dan sistem bahan bakar yang bagus sehingga dapat menurunkan keausan ruang piston.

5. Tidak mudah terbakar serta aman dalam penyimpanan karena tidak mengandung racun.

6. Dapat meningkatkan nilai produk pertanian.

7. Dapat diproduksi dalam skala kecil untuk di pedesaan.

8. Dapat menurunkan ketergantungan pada suplai minyak dari negara asing.

9. Dapat mudah terurai oleh mikroorganisme sehingga pencemaran bisa teratasi secara alami.

Banyak negara telah menggunakan biodiesel untuk keperluan sehari-hari, namun di Indonesia yang memiliki potensi bahan baku yang sangat besar belum melakukan langkah-langkah yang serius. Pengolahan biodiesel pada skala kecil menengah 
sangat membantu upaya pemberdayaan masyarakat dalam diversifikasi sumber energi terbaharukan.

\section{PENUTUP}

Berdasarkan paparan makalah diatas dapat diambil kesimpulan bahwa :

1. Bio Diesel dapat digunakan sebagai bahan bakar alternatif pengganti minyak solar dari fosil.

2. Pembuatan biodiesel dari tanaman jarak (Jatropha curcas Linneaus ) memiliki banyak keuntungan yang bisa dimanfaatkan . Salah satu contohnya adalah ampasnya bisa dipakai pupuk.

3. Biodiesel memiliki banyak keunggulan jika dibandingkan dengan bahan bakar solar.

\section{DAFTAR PUSTAKA}

Anita Pravitasari, Potensi Pengembangan Biodiesel di Indonesia http://destonline.com/blog Anita/2008/03/02/biodiesel-di-indonesia/

Anonim, 2001, Annual Report Biodiesel Word Flow.www.biodiesel.org/resources/reportdatabase/report/mar/mar-005.pdf.

Anonim, 2002. Berita harian Kompas tanggal 18 Maret 2002.

Anonim, 2005, Encyclopedia : Transesterification.www.WordiQ.com.

Biodiesel AUSTINDO - http://bahasa.biodieselindonesia.com/indexx.php.

Bambang Susilo. (2006), “Bio Diesel “,Trubus Agrisarana,Surabaya.

Rama Prihandana, Erliza H, Siti M, Roy H. (2007), "Meraup Untung Dari Jarak Pagar", Agromedia Pustaka,Jakarta.

Syamtori, Stanley. Biodiesel di Indonesia $\underline{\text { http://dest- }}$ online.com/blog_stanley/2008/03/02/biodiesel-di-indonesia/

Soeradjaja, T. H., 2003a. Energi alternatif biodiesel (Bagian 1), http://www.kimia.lipi.go.id/index.php?pilihan=berita\&id=13 
Soeradjaja, T. H., 2003b. Energi alternatif biodiesel (Bagian 2), http://www.kimia.lipi.go.id/index.php?pilihan=berita\&id=13

JPTK, UNDIKSHA, Vol. 7, No. 2, Juli 2010 : 47 - 58 